

\title{
FUNCTIONAL FOODS: MINIATURE PLANTS THAT PACK A BIG PUNCH!
}

\section{Bianke Loedolff* and Shaun Peters}

Department of Genetics, Institute for Plant Biotechnology, Stellenbosch University, Stellenbosch, South Africa

\section{YOUNG REVIEWER:}

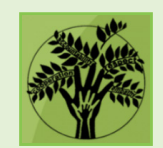

CROCKER FARM ELEMENTARY SCHOOL AGE: $10-11$
Plants provide us with a number of chemicals (called phytochemicals) that keep our bodies healthy. Many of these phytochemicals accumulate naturally as plants grow and they cannot be found in other foods like fish or meat, so plants are actually very important to humans! Really small plants having only four to six little leaves (called micro-greens) can contain up to 100 times more phytochemicals than their large versions, and this could make them very powerful in improving health, if they are included in our daily diets. We study micro-green versions of plants that we normally eat in our salads, like arugula and lettuce. By changing the environment in which the micro-greens grow, we can actually stimulate them to make a lot of phytochemicals that are beneficial to human health and well-being. These types of foods are called functional foods, because they actually make us healthier and help to prevent diseases. 


\section{PHYTOCHEMICALS}

Good chemicals that only plants can make, which help keep our minds and bodies healthy.

\section{DNA}

The little building blocks of life that tell our cells what to do. DNA is within each of our cells.

\section{CANCER}

A serious disease sometimes caused by free radicals.

\section{FREE RADICALS}

Bad chemicals that will damage anything they contact, (like our DNA, proteins and fats) and cause diseases such as cancer.

\section{STRESSFUL}

\section{CONDITIONS}

A condition can be stressful to plants (and humans) when there are lots of salt, high temperatures, too little water, or lots of bacteria that can cause sickness
We understand from a young age that fruits and vegetables are very important to our health, yet many of you may remember struggling to finish your brussels sprouts, peas, and broccoli at the dinner table. Why do plants play such a big role in keeping us healthy? Plants make good chemicals, called phytochemicals, which our bodies use to keep us healthy and to protect the DNA in our cells. DNA is a very important part of all life on earth and, in our bodies, DNA is like the boss telling our cells what to do and how to do it. If our DNA is sick or damaged, then we can develop serious diseases, like cancer ${ }^{1}$. Such damage to our DNA is caused by too many bad chemicals, called free radicals. We are able to fight this damage with the help of the phytochemicals plants provide when we eat them. So, remember that brussels sprouts, peas, and broccoli could actually be our health superheroes, because they make very important phytochemicals to protect our bodies from harmful villains called free radicals!

\section{WHY DO PLANTS MAKE PHYTOCHEMICALS IN THE FIRST PLACE?}

Have you ever wondered why flowers are so colourful? Or why fruits change colour as they ripen? Or even why leaves change colour when the season changes? These colours are the phytochemicals accumulating. Phytochemicals exist just about everywhere in plants and have many important functions that help plants grow and reproduce. For example, the colours of flowers are important to attract insects to pollinate them.

Plants also make a lot of phytochemicals that we cannot see, usually to help protect them from stressful conditions. These stresses can include drought (sparse rain, like in a desert), too much salt (for plants growing near the ocean), high levels of light (like the UV rays from the sun) and extremes of temperature (too hot or too cold). Plants have developed unique ways to use their phytochemicals to protect them. When plants are faced with stressful conditions (such as too much light) they can make more phytochemicals to fight the harmful free radicals. So, as scientists, we often try to find ways to grow plants under stressful conditions, so that the plants will make more of the phytochemicals that keep us healthy when we eat them.

\footnotetext{
https://www.youtube.com/watch?v=zwibgNGe4aY
} 


\section{PHYTOCHEMICALS ARE THE RAINBOWS IN THE PLANT WORLD THAT KEEPS US HEALTHY}

Plants make thousands of different phytochemicals that we know of, and probably a lot more that we have not yet discovered. Let us think about all the colours of the rainbow. All fruits and vegetables that we eat have unique colours, thanks to the phytochemicals! Interestingly, every colour is important to keep specific parts of our bodies healthy. When we eat plants, our bodies can use their phytochemicals (which we cannot make ourselves) to keep us healthy and prevent disease. In Figure 1, there is a rainbow. Each colour of the rainbow is represented by different fruits and vegetables, each with a unique colour (remember, the colours are the healthy phytochemicals!). Now you can trace that colour on the rainbow to see where in our bodies the colourful phytochemicals play an important role. Keep the rainbow in mind next time you have a plate of food, and remember which part of your body the food is going to keep healthy!

\section{HOW DO PHYTOCHEMICALS MAKE US HEALTHIER?}

To understand how phytochemicals protect us, we first need to understand that free radicals are very dangerous and quickly damage DNA in our cells. In the same way that free radicals accumulate within plants under stressful conditions, free radicals can also accumulate in our bodies, damage our DNA, and cause serious diseases. Humans cannot make

Figure 1

The rainbow of phytochemical colours in our fruits and vegetables. Trace the coloured lines from the various fruits and vegetables on the rainbow to find out where in our bodies the phytochemicals from these plants play an important role in keeping us healthy. The colours of the rainbow are represented by the following fruits and vegetables: redstrawberry; orangecarrot; yellow-sweet corn; green-peas; blue-blueberries: indigo-eggplant; violet -kohlrabi. Kohlrabi is a root vegetable, almost like a purple potato.

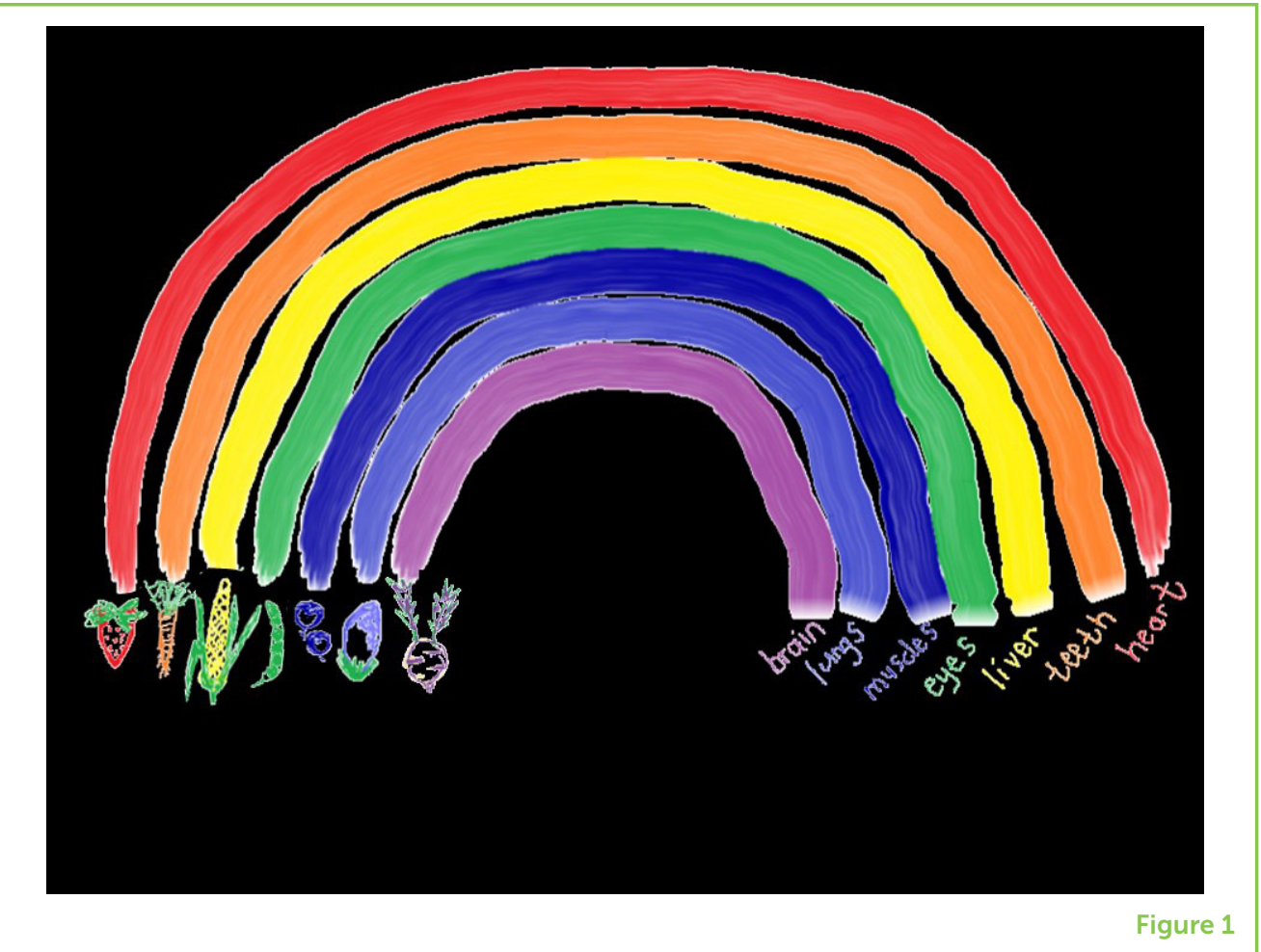




\section{ANTI-OXIDANTS}

Good chemicals that help fight against free radicals. The phytochemicals that plants make are natural anti-oxidants.

\section{MICRO-GREENS}

Mini versions of full-grown vegetables. They only have about six mini leaves.

\section{FUNCTIONAL} FOODS

Foods that contain high amounts of healthy chemicals.

phytochemicals and we therefore rely on eating enough plants to get the healthy phytochemicals we need to protect us from free radicals. These phytochemicals function as anti-oxidants ${ }^{2}$. Think of anti-oxidants as sponges, mopping up all the free radicals. This way, they can get rid of the free radicals that accumulate within our cells due to stressful conditions or unhealthy eating (like "junk" food). In the same way that UV rays from the sun can cause stressful conditions for your skin, "junk" food can also cause stressful conditions inside your body. These "junk" foods often have lots of free radicals, making them unhealthy for our bodies. So, when we eat fresh fruits and vegetables, our bodies use their phytochemicals to stop free radicals from damaging the DNA in our cells. This is why fast food restaurants now offer healthier meal options, including salads. It is very important to know that since phytochemicals function as anti-oxidants, the more plants we eat, the more anti-oxidants we have to protect our DNA from the harmful free radicals.

\section{MICRO-GREENS ARE SMALL PLANTS THAT HAVE EVEN MORE PHYTOCHEMICALS THAN USUAL}

Now let us look at very tiny plants, called micro-greens. These are smaller versions of everyday vegetables and salad greens that we know (broccoli, arugula, beetroot, and kale for example). Micro-greens have only four to six leaves, but these tiny leaves pack a very big phytochemical punch. Why is this so? Micro-greens are young plants and it is easier for stressful conditions to damage and kill them. To protect themselves, they have lots of phytochemicals. Now remember we mentioned that scientists are always looking for ways to stimulate plants to make more phytochemicals? Microgreens are perfect! They make lots of different phytochemicals, much more than older fruits and vegetables do. We call these micro-greens "functional foods", because they provide us with extra anti-oxidants to protect our cells from free radicals. You can grow your own micro-greens. All you need are some seeds from your favorite salad greens (like arugula, radish, mustard, kale) and you can grow tiny plants until they have four to six leaves. This will take about 21 days. After 21 days, you can eat a handful of these micro-greens and get a lot of healthy phytochemicals. Microgreens taste just like the older plants, maybe even better!

\section{HOW CAN WE MAKE THESE MICRO-GREENS EVEN HEALTHIER?}

Because stressful conditions lead to more phytochemicals in plants, we study how we can use stressful conditions to make even more

${ }^{2}$ https://www.livestrong.com/article/520253-information-for-kids-on-antioxidants/ 
BIO-FORTIFICATION

A special way to grow plants, so that they make more phytochemicals.

\section{Figure 2}

Amounts of antioxidants in arugula, kale and radish microgreens. We use a scale from 0 (no antioxidants) to 1000 (lots of anti-oxidants) to compare the level of anti-oxidants in the micro-greens when they are grown under normal (low light) and bio-fortified (high light) conditions. When the micro-greens are grown under high light, they make more phytochemicals, which means that they have much anti-oxidants to help fight against free radicals. You can see the red/purple colour of the micro-greens grown under high light, and the green colour of those grown under low light. The red/purple colour tells us that there are lots of phytochemicals being made. phytochemicals in micro-green plants. This is called bio-fortification. In our laboratory we use very high levels of light (almost like UV rays from the sun that can cause sunburn if we do not use our sunscreen) to grow micro-greens. By doing this we create a stressful condition that causes the micro-greens to make more phytochemicals to help protect them from the light-think of the plants using their phytochemicals as sunscreen! We now have micro-greens that are even healthier for our bodies, because they have even more phytochemicals. For example, we have recently published a study [1] in which we grew arugula microgreens in normal growing conditions (low light) and then abnormal growing conditions (high light). Under normal growing conditions, the arugula micro-greens are green, but the high light caused a stressful condition that turned them a red/purple colour, because they made more phytochemicals!

\section{CAN WE PROVE IN THE LABORATORY THAT THESE BIO-FORTIFIED MICRO-GREENS HAVE THE POTENTIAL TO PREVENT SERIOUS DISEASES?}

Lots of tests need to be done to see if our micro-green phytochemicals actually help our bodies to be healthier. We need to investigate if the phytochemicals really do their job as anti-oxidants (fighting the bad free radicals). To do this, we used a test to see what their Total Anti-oxidant Capacity (TAC) is. The higher the TAC, the better the phytochemicals are at doing their anti-oxidant job of fighting the harmful free radicals. We tested the effects of high levels of light as a way of growing microgreens from radish, kale, and arugula. Look at Figure 2 to see how more

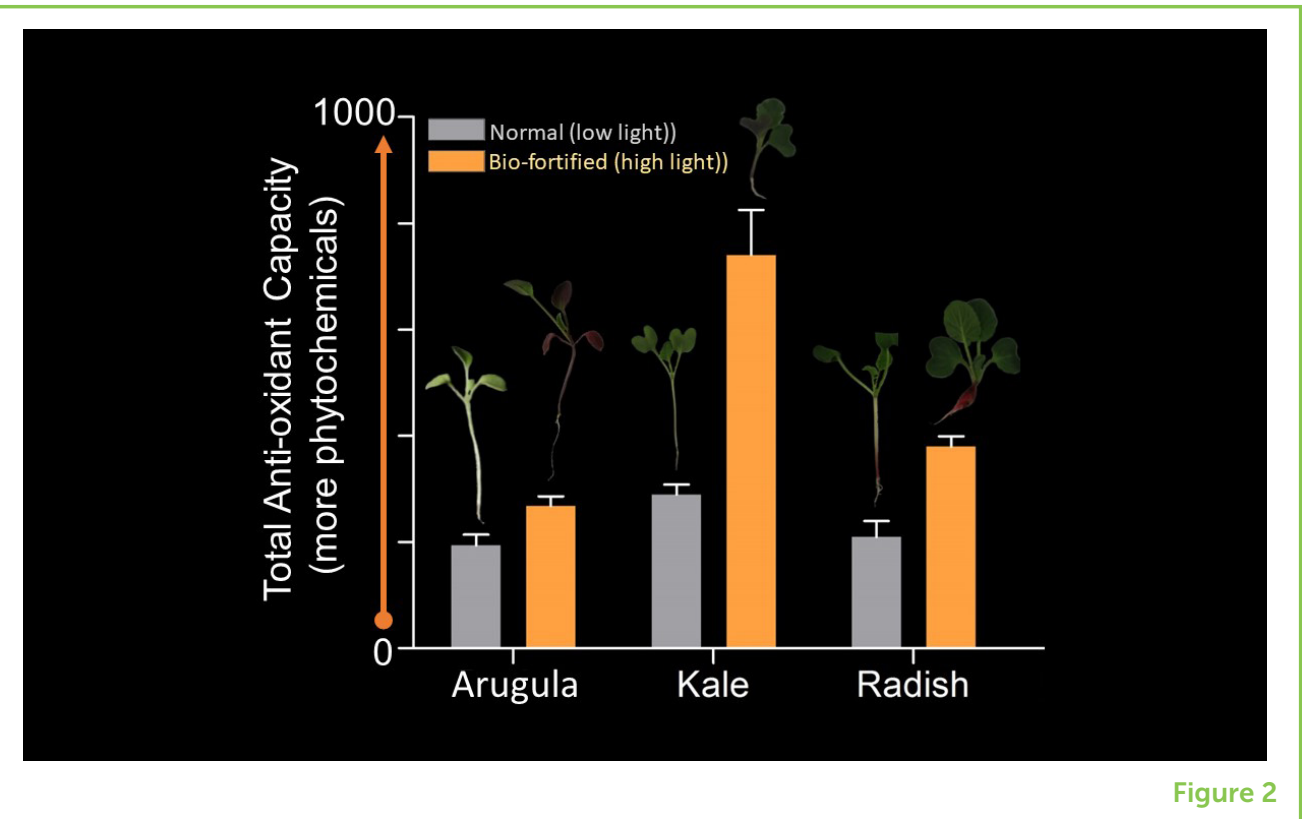




\section{GEL}

\section{ELECTROPHORESIS}

A technique used by scientists to separate different forms of molecules such as DNA and proteins. phytochemicals provide more TAC, meaning that these micro-greens will fight more free radicals. This graph shows you how much antioxidants are in the micro-greens. We use a scale from nothing (0) to a lot (1,000), to compare micro-greens grown under normal (low) and abnormal (high) light. There are more anti-oxidants when micro-greens are grown under high light, which tells us that our way of growing these little plants is really making them into health superheroes!

Can the increased TAC in the micro-greens protect DNA from free radical damage? To study this, we did an experiment called a DNA protection assay. Remember, DNA can very quickly be damaged by free radicals if there are not enough anti-oxidants around. To do this experiment, we remove human DNA from cells to study it. How do we look at what happens to DNA when it is outside the body? We use a special technique called gel electrophoresis. This technique can be used to separate damaged DNA from undamaged DNA, by letting the DNA move through a slab of gel (think of it like thick Jell-o) from the top, where the DNA is added, to the bottom. Using a special stain on the gel, the DNA will appear as bands. Healthy, undamaged DNA will move faster through the gel and a band will appear near the bottom of the gel. Damaged DNA will move slowly through the gel and a band will appear near the top. The following experiment might help you understand how we do this.

\section{THE GEL ELECTROPHORESIS EXPERIMENT}

For this experiment it is important to remember the difference between damaged and undamaged DNA and, how we can see this difference on a gel. Isolated DNA can be damaged in the lab with a harmful free radical, a chemical called hydrogen peroxide. We can test if the micro-greens have enough anti-oxidants to protect the DNA from free radical damage. To do this, we first mix the isolated DNA with micro-green juices. This DNA is then exposed to the free radical hydrogen peroxide. To know whether our micro-green anti-oxidants are doing their job properly, we look at the DNA on a gel to see if it is damaged or healthy. If it is healthy, it means it was protected by the anti-oxidants in the micro-green juices.

Figure 3 shows a picture of this experiment. You can see normal DNA, which has not been damaged, as well as DNA damaged by hydrogen peroxide and DNA protected by micro-green anti-oxidants. To help you understand, we drew a red line on the figure. The DNA band that is above the red line means the DNA is damaged. The DNA band below the red line means the DNA is protected. This experiment showed us that DNA mixed with micro-green phytochemicals is protected from damage by free radicals. By doing these types of experiments, we are 


\section{Figure 3}

The DNA protection assay experiment. In the lab, DNA is seen as bands when a technique called gel electrophoresis is used Normal DNA is shown under the left test tube. Under the middle test tube, you can see DNA that has been damaged by the free radical hydrogen peroxide. Under the third test tube, you can see DNA protected from the hydrogen peroxide damage, because the DNA was mixed with the good, protective phytochemicals from micro-greens. The red line helps you see that damaged DNA moves slowly through the gel and will therefore be closer to the top.

Normal, protected DNA moves more quickly through the gel and will therefore be near the bottom.

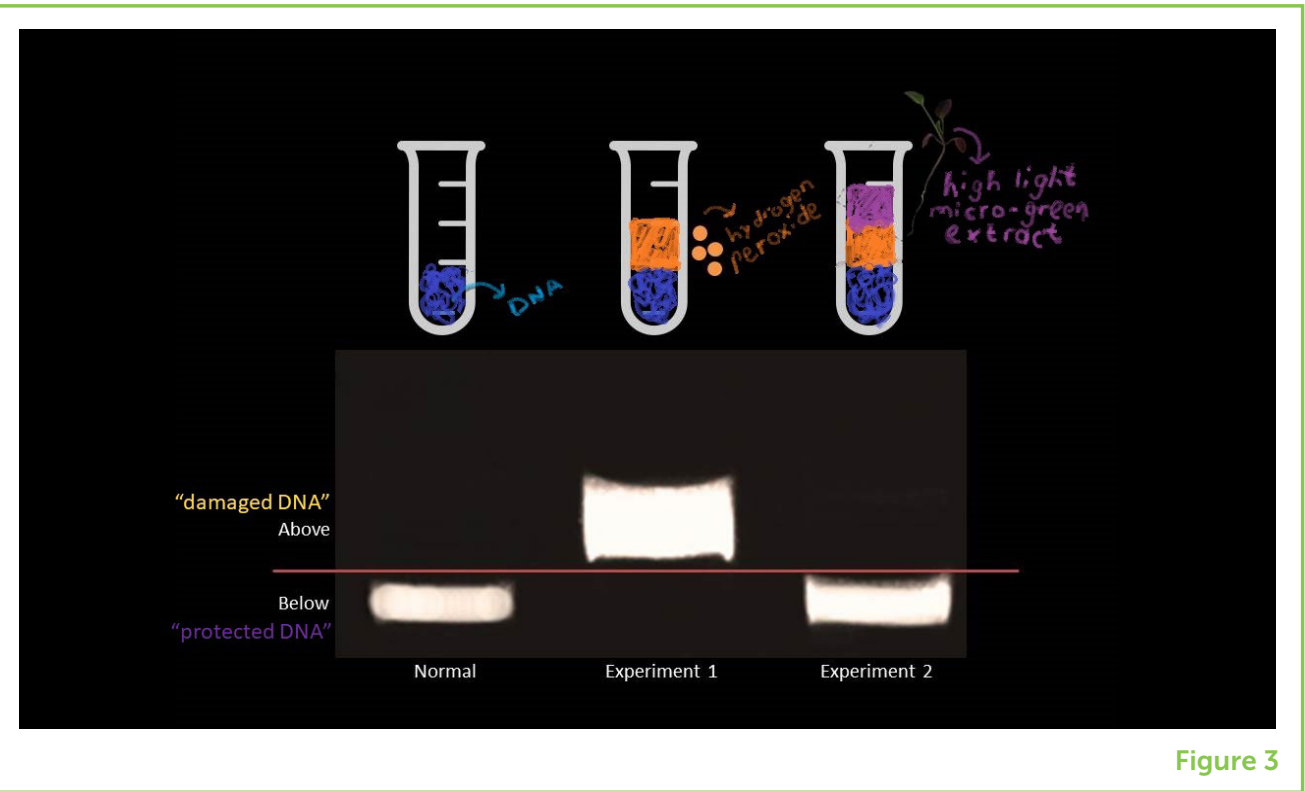

taking the first steps to show that micro-green phytochemicals can protect DNA from free radical damage and that eating these micro-greens might protect our bodies from free radical damage, keeping us healthy!

\section{SUMMARY}

Plants naturally make a lot of different phytochemicals that help protect them from stressful conditions. When we eat plants, their phytochemicals can help our bodies to be healthy and even help prevent us from getting serious diseases, like cancer. These phytochemicals act as anti-oxidants that fight free radicals, which cause serious damage to our cells. We do research on micro-green bio-fortification (making more healthy phytochemicals) by growing them under stressful conditions to make more and more phytochemicals. We then test the phytochemicals from micro-greens to show how good they are at protecting our DNA. Our hope is to design a mixture of lots of different kinds of bio-fortified micro-greens (like arugula, mustard, kale, radish and many more) that we can eat to help protect our bodies from free radical damage. So, the next time you think about not eating your "yucky" brussels sprouts and broccoli, remember the story of micro-greens and how healthy they are.

\section{REFERENCE}

1. Loedolff, B., Brooks, J., Stander, M., Peters, S., and Kossmann, J. 2017. High light bio-fortification stimulates de novo synthesis of resveratrol in Diplotaxis tenuifolia (wild rocket) micro-greens. Funct. Foods Health Dis. 7:859-72. doi: $10.31989 /$ ffhd.v7i11.380 
SUBMITTED: 12 March 2018; ACCEPTED: 13 September 2018; PUBLISHED ONLINE: 01 October 2018.

EDITED BY: Viduranga Y. Waisundara, Rajarata University of Sri Lanka, Sri Lanka

CITATION: Loedolff B and Peters S (2018) Functional Foods: Miniature Plants that Pack a Big Punch! Front. Young Minds 6:52. doi: 10.3389/frym.2018.00052

CONFLICT OF INTEREST STATEMENT: The authors declare that the research was conducted in the absence of any commercial or financial relationships that could be construed as a potential conflict of interest.

COPYRIGHT @ 2018 Loedolff and Peters. This is an open-access article distributed under the terms of the Creative Commons Attribution License (CC BY). The use, distribution or reproduction in other forums is permitted, provided the original author(s) and the copyright owner(s) are credited and that the original publication in this journal is cited, in accordance with accepted academic practice. No use, distribution or reproduction is permitted which does not comply with these terms.

\section{YOUNG REVIEWER}

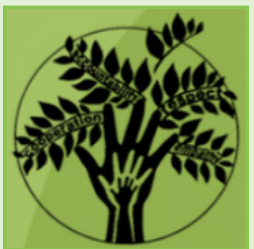

\section{CROCKER FARM ELEMENTARY SCHOOL, AGE: 10-11}

We are 5th graders at Crocker Farm Elementary School in Amherst MA, USA. We worked on this review with the help of our science mentor and a science outreach group of Amherst College students (co-captains Liz and Chris). We enjoyed learning about functional food and the process of peer review.

\section{AUTHORS}

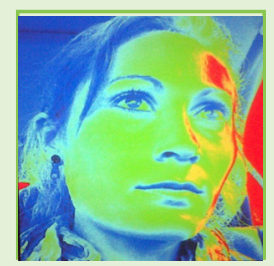

\section{BIANKE LOEDOLFF}

From a young age, I have had a passion for plants and the nutritious chemicals they make. This passion led me to become a scientist to further understand just why plants are so special. My main research interest focuses on human nutrition and how we can use plants to keep us healthy. Science is not my only passion; I am also a keen artist and enjoy spending my free time painting or sketching (this actually helps me think about my nutritional research). In essence, my world is driven by colour, be it art or science. *bianke@sun.ac.za

\section{SHAUN PETERS}

I have been fascinated by biology since I was a kid. My hero, Sir David Attenborough, has been making nature documentaries for television since 1954! This helped greatly when I chose what subjects to study at school and university-biology of course! After completing my doctoral studies in Switzerland, I returned to my home country of South Africa and now work at the Institute for Plant Biotechnology (Stellenbosch University). I am passionate about science education and studying how plants work. In my spare time I enjoy reading and spending time with my daughter Arya. 